\title{
APPENDIX \\ VI. GEOCHEMISTRY OF CARBON: DSDP LEGS 22, 24, 26, 27, AND 28
}

\author{
J. G. Erdman, K. S. Schorno, and R. S. Scanlan, Phillips Petroleum Company, Bartlesville, Oklahoma
}

\section{INTRODUCTION}

A total of 18 samples from the Indian Ocean, Legs 22, $24,26,27$, and 28 has been received through the JOIDES Organic Geochemistry Subcommittee. The locations of the holes from which these samples came are shown in Figure 1. The samples were collected in their plastic liners, frozen onboard ship and maintained frozen thereafter.

\section{SAMPLE AND STUDY PROCEDURES}

The samples were split using a circular saw by cutting a channel down each side of the plastic liner. Cuttings were removed with a brush and the final cut was made with a sharp knife. The sample was then supported in a jig, allowed to thaw, and split using a piece of steel wire.

The flat surfaces of the samples were smoothed for description and photographing, using a milling machine and flycutter. Photographs of the samples are provided in Figures 2-19 along with overlay diagrams of textural and color patterns. Chips of each textural type of lithology were removed for determination of carbonate carbon and organic carbon. The values are found in Table 1. The vertical (top-bottom) orientation of the samples unfortunately was not recorded onboard ship. The remaining determinations described herein were made on linear strips of the sample.

The workup procedure for carbon types is shown diagramatically in Figure 20. The solvents were distilled in glass immediately before use. Each analytical determination was performed in duplicate.

\section{RESULTS AND DISCUSSION}

The sampling sites are scattered over a broad lateral area of the Indian Ocean (Figure 1). Data representative of the bulk samples, i.e., the average for the entire sample, are provided in Tables 2 and 3. The calcium carbonate concentrations are calculated from the carbonate carbon values.

Samples from the Bay of Bengal sites (Holes 217A and 217) are light colored, very calcareous, plastic muds. They generally have low total organic carbon and high carbonate carbon contents. There are no obvious correlations between carbon contents, isotopic compositions, or age (depth). Samples from Site 218 are richer in organic carbon and have lower carbonate carbon contents. Again, there are no apparent correlations between these data.

Samples from Holes 232A, 233, and 233A in the Gulf of Oman are generally dark gray or olive-gray, calcareous, plastic clays. They are unusually rich in organic matter considering that the samples are also quite calcareous. The organic carbon in these samples is isotopically heavy, resembling that of warm-water plankton or areas where
TABLE 1

Carbonates and Organic Carbon Values for Inclusions Notes in Figures 2-19

\begin{tabular}{|c|c|c|c|c|}
\hline \multirow[b]{2}{*}{ Figure } & \multirow[b]{2}{*}{ Inclusion } & \multicolumn{2}{|c|}{ Carbonates } & \multirow{2}{*}{$\begin{array}{l}\text { Organic } \\
\text { Carbon } \\
\text { (wt \%) }\end{array}$} \\
\hline & & $\begin{array}{r}\text { Carbon } \\
\text { (wt \%) }\end{array}$ & $\begin{array}{r}\text { Calcium } \\
\text { (wt \%) }\end{array}$ & \\
\hline 2 & $\begin{array}{l}1 \\
2\end{array}$ & $\begin{array}{l}6.23 \\
6.00\end{array}$ & $\begin{array}{l}51.9 \\
50.0\end{array}$ & $\begin{array}{l}0.28 \\
0.63\end{array}$ \\
\hline 3 & $\begin{array}{l}1 \\
2 \\
3\end{array}$ & $\begin{array}{r}12.21 \\
8.75 \\
8.31\end{array}$ & $\begin{array}{r}100.0 \\
79.9 \\
69.3\end{array}$ & $\begin{array}{l}0.23 \\
0.11 \\
0.23\end{array}$ \\
\hline 4 & $\begin{array}{l}1 \\
2\end{array}$ & $\begin{array}{r}10.04 \\
5.13\end{array}$ & $\begin{array}{l}83.7 \\
42.6\end{array}$ & $\begin{array}{l}0.09 \\
0.04\end{array}$ \\
\hline 5 & $\begin{array}{r}1 \\
\text { AZII } \\
\mathrm{B} \\
\mathrm{C}\end{array}$ & $\begin{array}{r}6.09 \\
10.78 \\
2.57 \\
11.07\end{array}$ & $\begin{array}{l}50.75 \\
89.8 \\
21.4 \\
99.8\end{array}$ & $\begin{array}{l}0.12 \\
0.09 \\
0.10 \\
0.09\end{array}$ \\
\hline 6 & 1 & 10.15 & 84.6 & 0.18 \\
\hline 7 & $\begin{array}{l}1 \\
2\end{array}$ & $\begin{array}{l}0.5 \\
0.48\end{array}$ & $\begin{array}{l}4.2 \\
4.0\end{array}$ & $\begin{array}{l}1.05 \\
0.52\end{array}$ \\
\hline 8 & $\begin{array}{l}1 \\
2 \\
3\end{array}$ & $\begin{array}{l}1.55 \\
0.81 \\
2.86\end{array}$ & $\begin{array}{r}12.92 \\
6.75 \\
23.83\end{array}$ & $\begin{array}{l}0.32 \\
0.30 \\
0.22\end{array}$ \\
\hline 9 & $\begin{array}{l}1 \\
2 \\
3 \\
4 \\
5 \\
6\end{array}$ & $\begin{array}{l}1.25 \\
1.27 \\
1.26 \\
1.23 \\
1.21 \\
1.37\end{array}$ & $\begin{array}{l}10.42 \\
10.58 \\
10.50 \\
10.75 \\
10.08 \\
11.42\end{array}$ & $\begin{array}{l}0.34 \\
0.31 \\
0.21 \\
0.15 \\
0.13 \\
0.32\end{array}$ \\
\hline 10 & $\begin{array}{l}1 \\
2\end{array}$ & $\begin{array}{l}5.85 \\
4.45\end{array}$ & $\begin{array}{l}48.8 \\
37.1\end{array}$ & $\begin{array}{l}2.59 \\
2.02\end{array}$ \\
\hline 11 & 1 & 5.34 & 44.5 & 1.95 \\
\hline 12 & $\begin{array}{l}1 \\
2\end{array}$ & $\begin{array}{l}5.25 \\
4.89\end{array}$ & $\begin{array}{l}43.8 \\
40.8\end{array}$ & $\begin{array}{l}2.71 \\
3.04\end{array}$ \\
\hline 13 & $\begin{array}{l}1 \\
2 \\
3 \\
4\end{array}$ & $\begin{array}{l}1.92 \\
2.10 \\
2.37 \\
2.65\end{array}$ & $\begin{array}{l}16.0 \\
17.5 \\
19.8 \\
22.1\end{array}$ & $\begin{array}{l}1.32 \\
1.20 \\
1.17 \\
1.43\end{array}$ \\
\hline 14 & $\begin{array}{l}1 \\
2 \\
3\end{array}$ & $\begin{array}{l}4.44 \\
0.17 \\
0.52\end{array}$ & $\begin{array}{r}37.0 \\
1.4 \\
4.3\end{array}$ & $\begin{array}{l}0.19 \\
0.19 \\
0.16\end{array}$ \\
\hline 15 & 1 & 0.08 & 0.7 & 2.50 \\
\hline 16 & $\begin{array}{l}1 \\
2 \\
3 \\
4 \\
5\end{array}$ & $\begin{array}{l}0.1 \\
0.06 \\
0.74 \\
0.07 \\
0.06\end{array}$ & $\begin{array}{l}0.83 \\
0.50 \\
6.2 \\
0.58 \\
0.50\end{array}$ & $\begin{array}{l}0.1 \\
0.07 \\
0.15 \\
0.11 \\
1.76\end{array}$ \\
\hline 17 & 1 & 0.07 & 0.01 & 0.08 \\
\hline 18 & $\begin{array}{l}1 \\
2 \\
3\end{array}$ & $\begin{array}{l}0.26 \\
3.66 \\
0.48\end{array}$ & $\begin{array}{r}2.2 \\
30.5 \\
4.0\end{array}$ & $\begin{array}{l}0.58 \\
0.65 \\
0.53\end{array}$ \\
\hline 19 & $\begin{array}{l}1 \\
2\end{array}$ & $\begin{array}{l}0.02 \\
1.06\end{array}$ & $\begin{array}{l}0.2 \\
8.8\end{array}$ & $\begin{array}{l}0.04 \\
0.18\end{array}$ \\
\hline
\end{tabular}




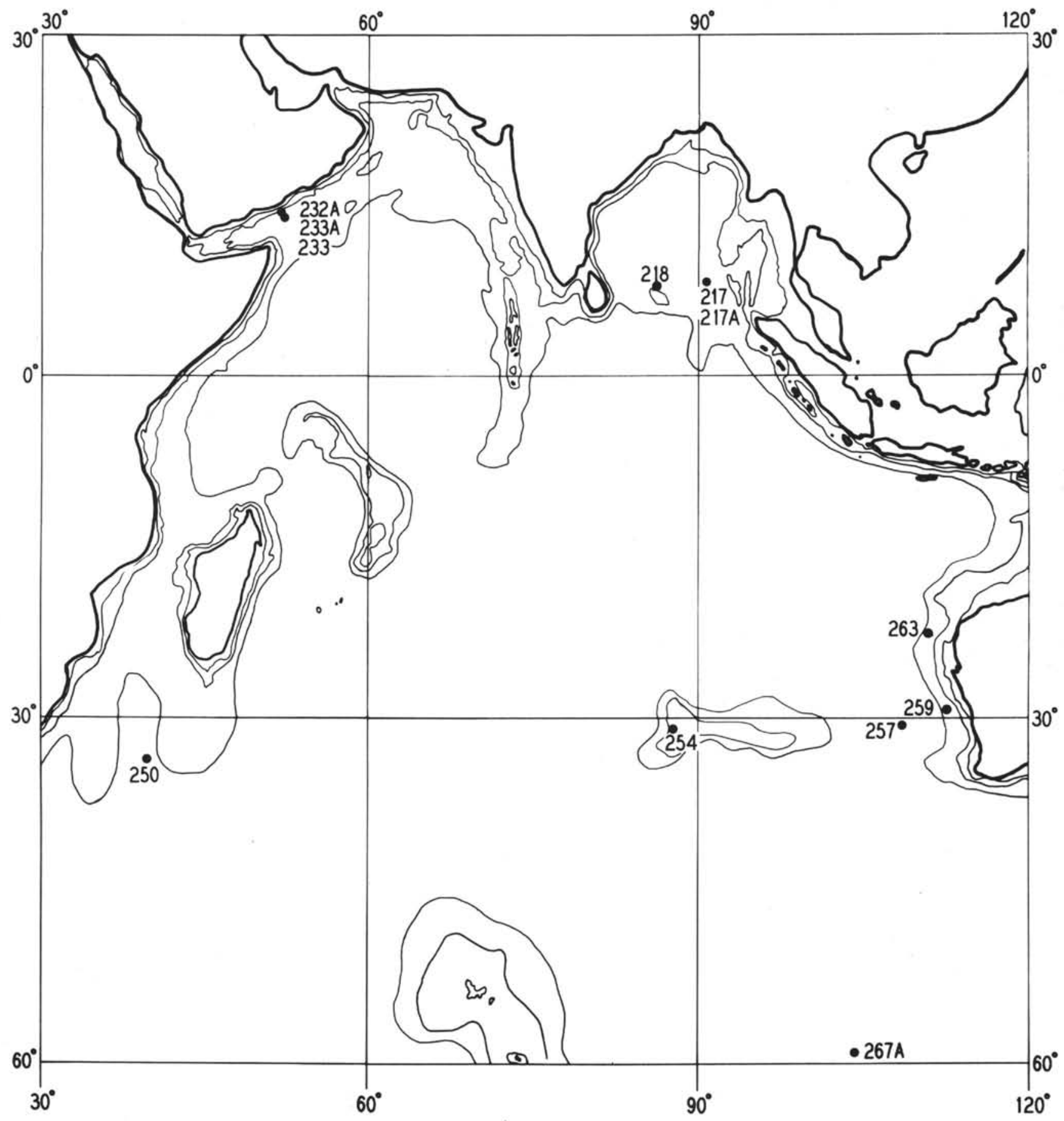

Figure 1. Location of holes from which samples for geochemical study were produced. 


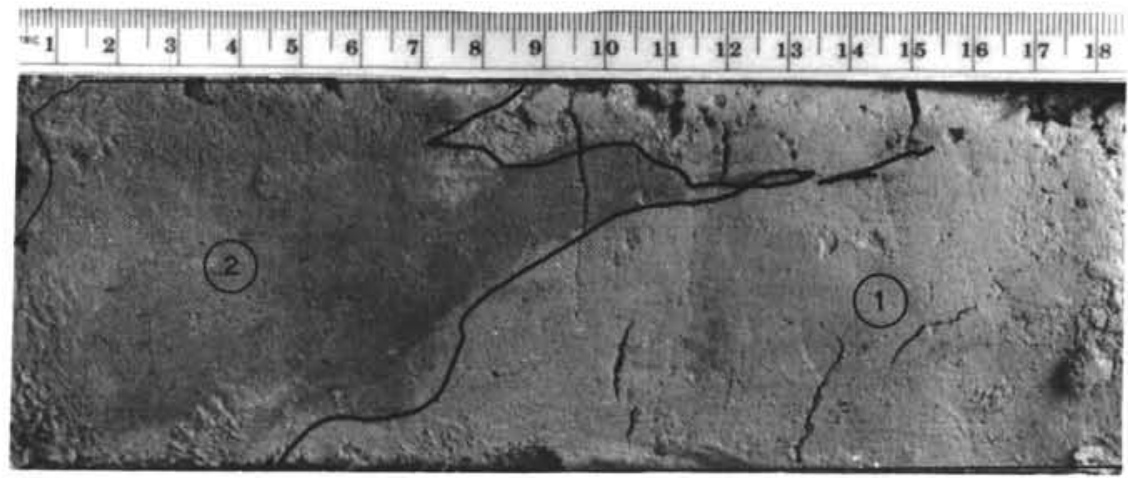

Figure 2. Leg 22, Site 217 (Hole 217A), Core 1, Section 3. Unit 1 - light gray (N7), soft, plastic, nonlaminated, clayey, planktonic foraminiferal ooze. Approximately $80 \%$ planktonic foraminifera and $20 \%$ calcareous nannoplankton. Unit 2 - medium gray (N5), soft, plastic, nonlaminated, clayey, planktonic foraminiferal ooze. No noticeable laminae or bedding. Irregular contact between units 1 and 2 appears as sharp boundary, largely due to a change in color. No appreciable variation in grain size or mineralogy from unit 1 to unit 2 . Unit 2 contains some widely disseminated tiny "specks" of a jet black color.

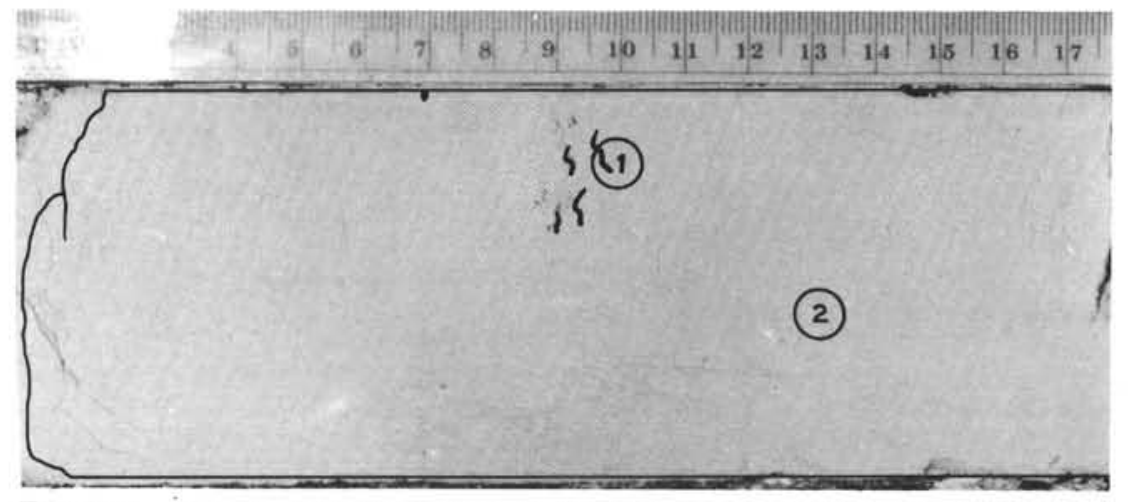

Figure 4. Leg 22, Site 217, Core 8, Section 5. Very light gray (N8) to white (N9) soft but firm and consolidated; nonlaminated, calcareous ooze. Appears to be uniform with a region of dark flecks (area no. 1).

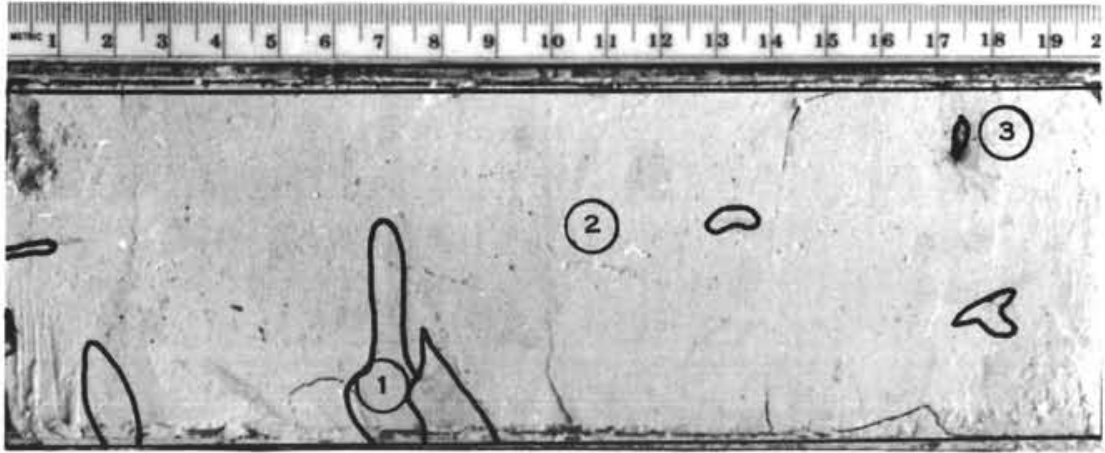

Figure 3. Leg 22, Site 217, Core 4, Section 4. Clay very calcareous, light greenish-gray $(5 G 8 / 1)$, mottled, plastic, firm silty with probable shell debris; bedding appears to have been disturbed by animal borings.

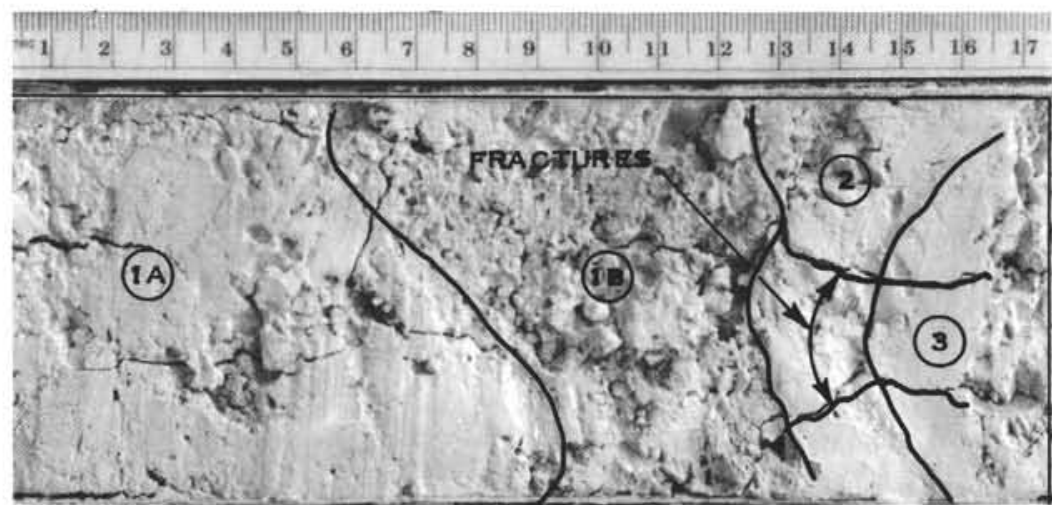

Figure 5. Leg 22, Site 217, Core 15, Section 3. Unit $1 A$ - pale pink $(5 R P 8 / 2)$ to grayish-orange-pink (10R 8/2), soft but firm nonlaminated, nanneplankton ooze. No foraminifera. Approximately $95 \%$ calcareous nannoplankton. Presence of light brown (5 YR 5/6) to moderate reddish-orange $(10 R 6 / 6)$ silt size to very coarse sand size fragments of ferruginous chert. Approximately $10 \%$ to $15 \%$ of this unit. Unit $1 B-$ same as above except that the angular chert fragments constitute up to $30 \%$ of unit. Unit 2 - grayish pink $(5 R 8 / 2)$, soft, plastic nonlaminated, clayey nannoplankton ooze. $98 \%$ to $99 \%$ calcium carbonate with little or no acid-insoluble fraction. Contact with Unit $1 B$ appears sharp. No chert fragments observed in this unit. Unit 3 - very light gray (N8) to pinkish-gray (5 YR 8/1), firm semiconsolidated, nonlaminated, blocky fracturing nannoplankton ooze. Grain size identical to that in Unit 2. Insoluble residue indicates this unit to consist of $98 \%$ to $99 \%$ calcium carbonate. 


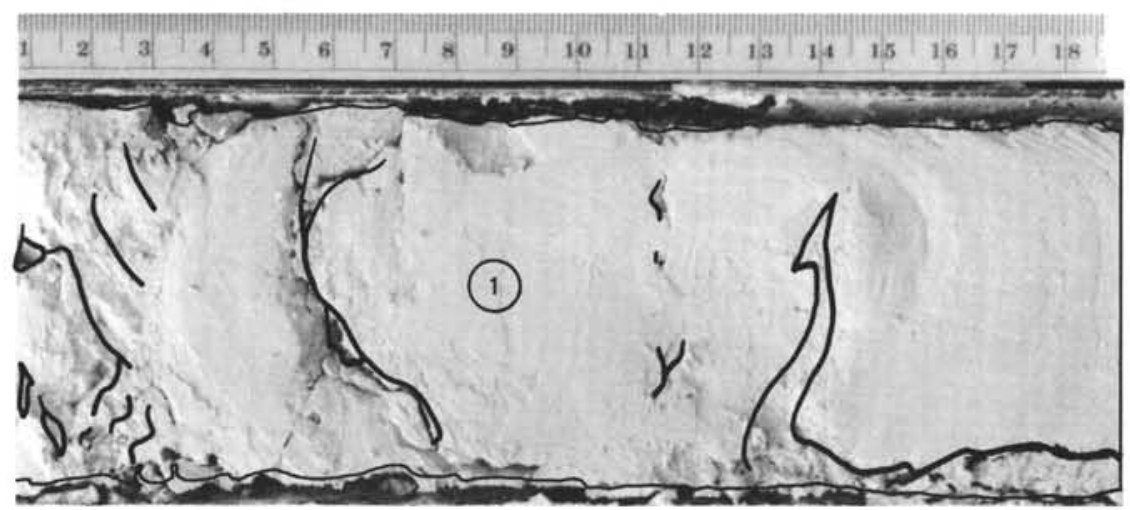

Figure 6. Leg 22, Site 217, Core 19, Section 3. Very light gray (N8) to pinkish-gray (5 YR 8/1), soft but firm and consolidated, nonlaminated, nannoplankton ooze. Approximately 3\% to 5\% insoluble clay size fraction. Appears to be $95 \%$ to $97 \%$ calcareous nannoplankton.

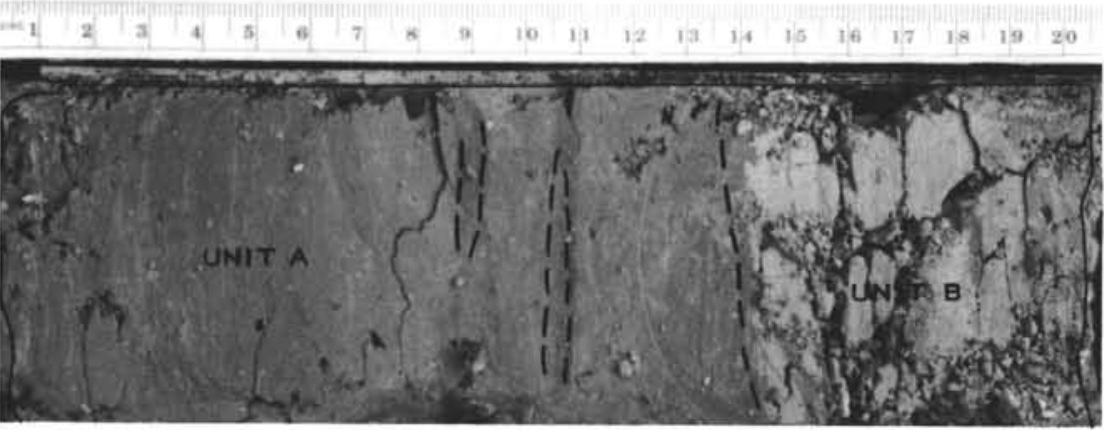

Figure 8. Leg 22, Site 218, Core 24, Section 2. Unit A-medium gray, $(N-5)$ medium soft laminated clay that is crumbly rather than being plastic. About $9 \mathrm{~cm}$ from top is a 4-mm dark gray (N-4) zone that has indistinct contacts; $1.6 \mathrm{~cm}$ above this is another similar band of $4 \mathrm{~mm}$ thickness. Both of these laminae appear to be more organic rich than enclosing clay of Unit $A$. Unit B - olive-gray $(5 Y 4 / 1)$, laminated clay more indurated than Unit A. Clay is not sandy and not plastic, and appears to contain microfossils.

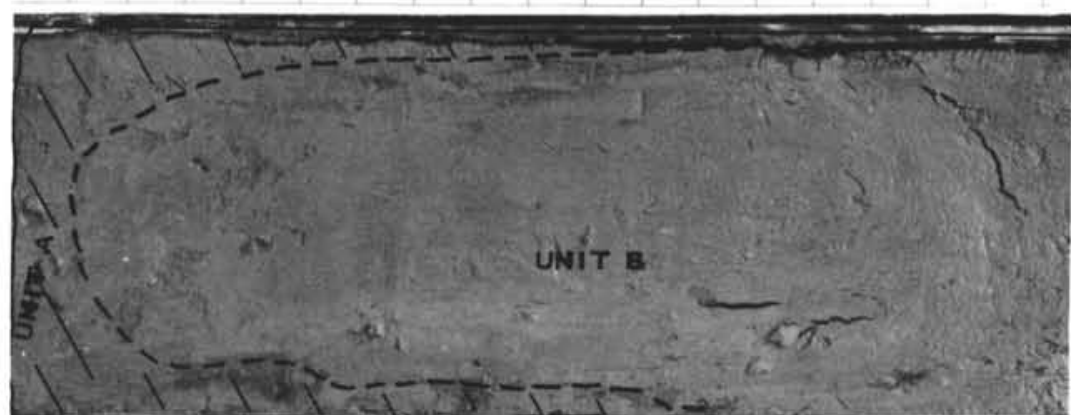

Figure 7. Leg 22, Site 218, Core 4, Section 2. Unit A - disturbed clay that forms a sheath around main lithology B. Appears lithology A plastic flowed up inside of core liner enclosing younger lithology B. Unit A very soft, dark gray $(N-3)$ mud ooze. Unit B - medium dark gray $(N-4)$ homogeneous laminated clay that does not appear to contain sand. Clay is soft and quite plastic.

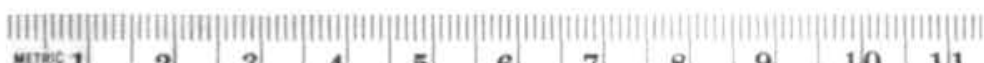

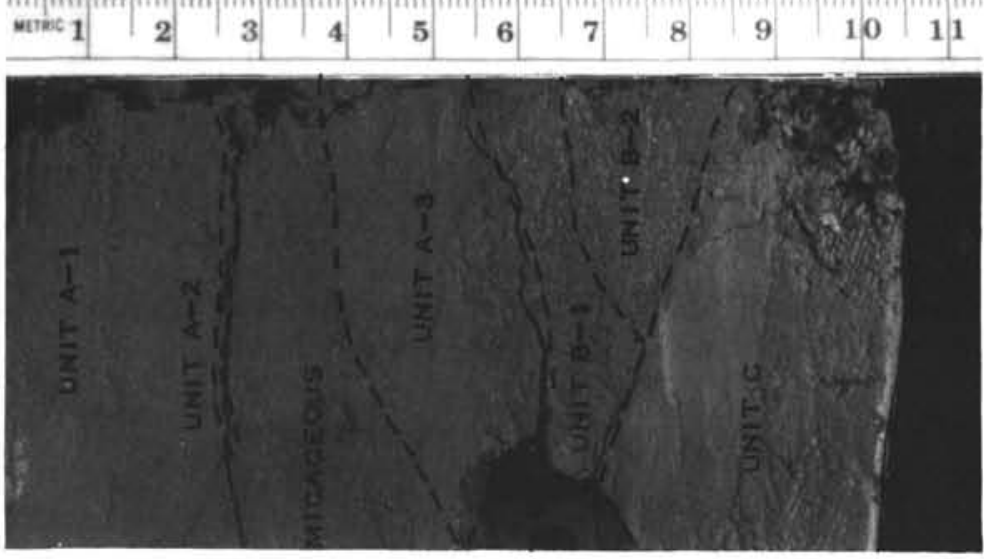

Figure 9. Leg 22, Site 218, Core 26, Section 2. Unit A - medium gray (N4), laminated, medium soft plastic clay, bedding is slightly irregular and $1.0 \mathrm{~mm}$ dark gray laminae of probable inorganic origin present $3.3 \mathrm{~cm}$ from top. Upper surfaces of these laminae appear to display "flame-structure." Below this dark laminae appears to contain finely dispersed mica or possibly quartz grains. Unit $B$ - consists of 2 lithologies, $B-1$ and B-2. B-1 consists of light yellowish-green-gray (5Y 4/1) fine-grained sandy clay. B-2 is dark gray (N1) sandy clay which appears to contain $0.05 \mathrm{~mm}$ flakes of mica. Unit C - same as Unit A only more homogeneous and does not contain dark laminae. Unit D - sample excavated from core liner. 


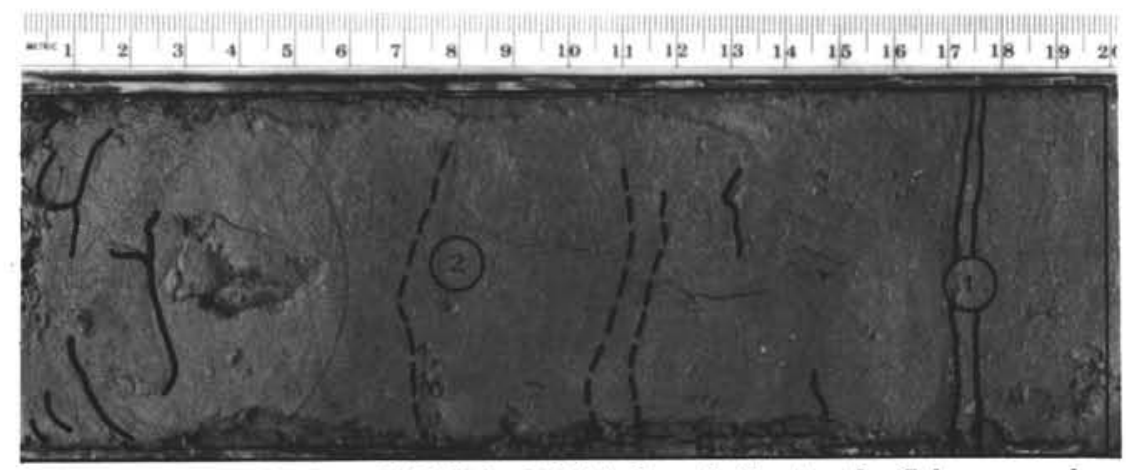

Figure 10, Leg 24, Site 233 (Hole 233A), Core 1, Section 3. Calcareous clay, olive-gray (54 4/1) soft plastic, massive with less than $0.5 \mathrm{~mm}$ darker lenses and laminae interspersed throughout interval. Core is homogeneous.

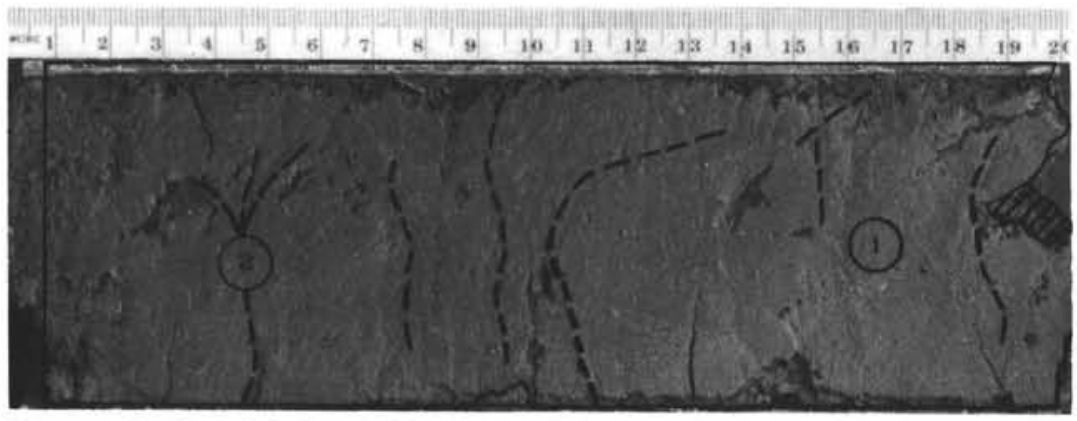

Figure 12. Leg 24, Site 233 (Hole 233A), Core 7, Section 4. Clay, very calcareous olive-gray (5Y 3/2) to light olive gray (5Y 5/2) soft, plastic, silty massive with suggestion of organic laminae interspersed throughout interval. Core is homogeneous in character.

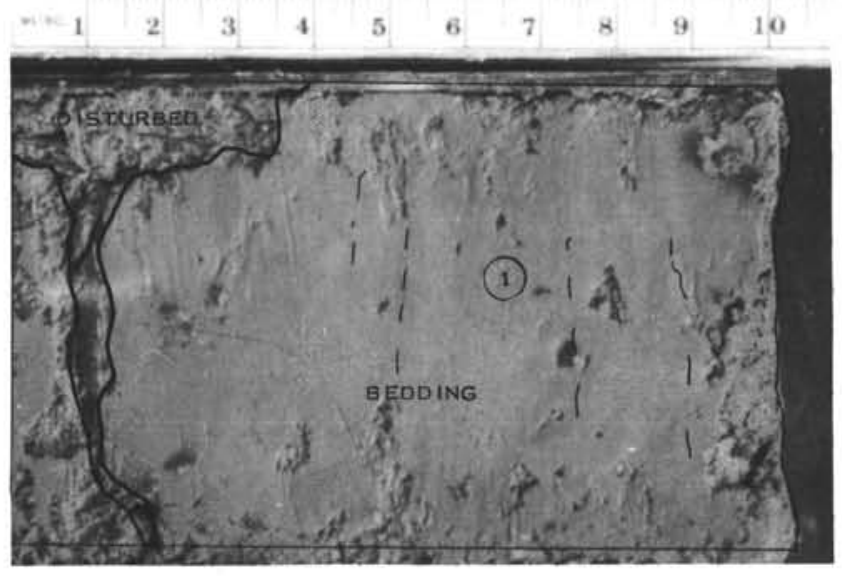

Figure 11. Leg 24, Site 233, Core 19, Section 5. Dusky yellowish-green (5GY 5/2), soft, very plastic silty calcareous clay. Homogeneous throughout length of core.

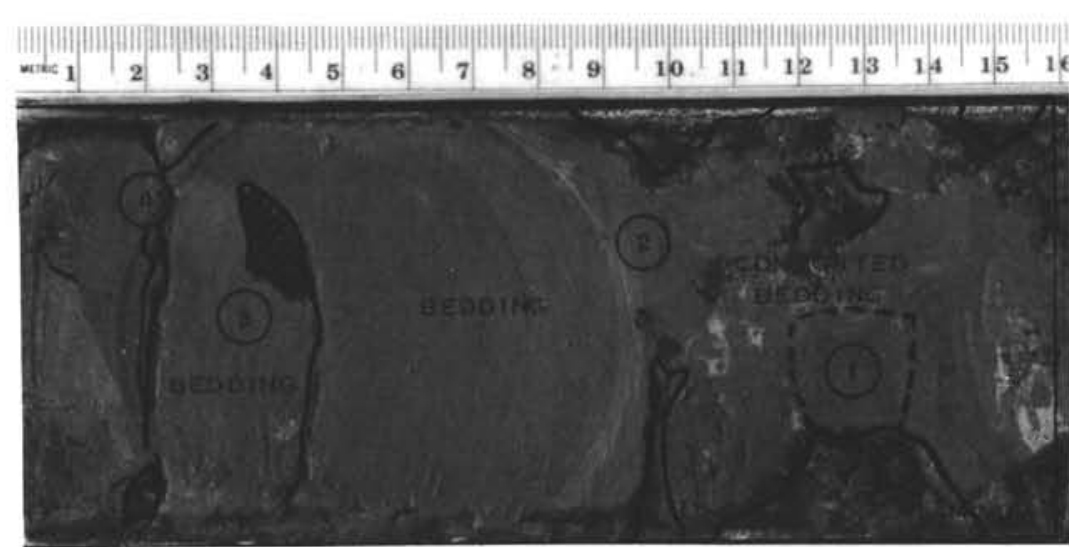

Figure 13. Leg 24, Site 232 (Hole 232A), Core 15, Section 2. Clay calcareous dark gray (N3) very plastic and soft. Partially contorted as result of coring, but evenly bedded portion contains 1-mm organic-rich laminae: Clay contains silty zones between organic laminae. 


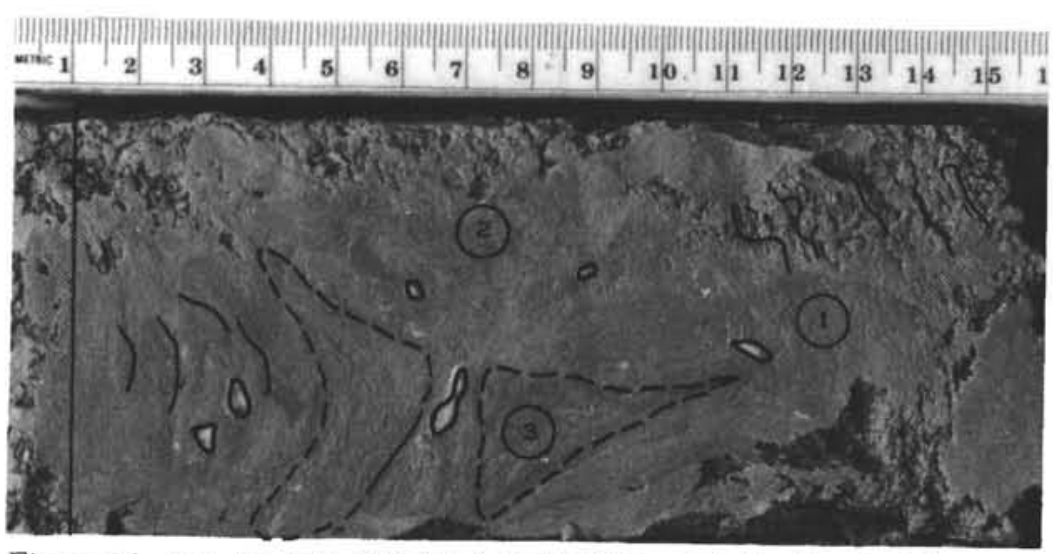

Figure 14. Leg 26, Site 250 (Hole 250A), Core 10, Section 6. Clay, very calcareous gray $(5 G Y / 4 Y)$ soft, plastic. Clay is contorted as a result of coring process. Zone $A$ is sharply folded and is grayish-red-purple $(5 R P 4 / 2)$ in color; with exception of this zone core is homogeneous in character.

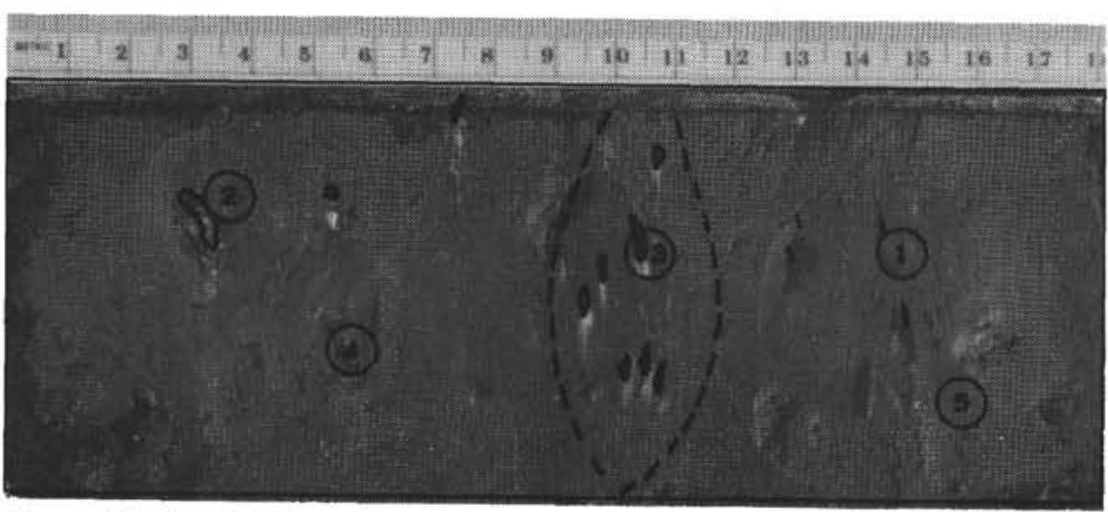

Figure 16. Leg 26, Site 257, Core 9, Section 3. Moderate brown (5YR414), soft clay ooze; bedding contorted and white blebs in center and dark flecks present throughout but concentrated in a $2-\mathrm{cm}$ band beneath the white blebs. Area no. 2 pale green clay fleck in top appears to be detrital clay fragment.

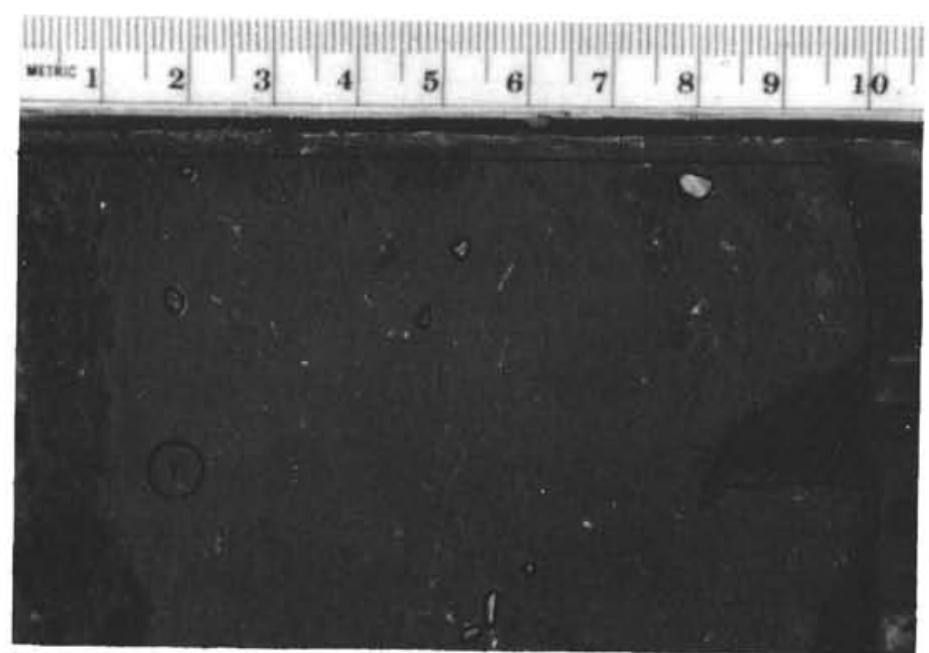

Figure 15. Leg 26, Site 254, Core 25, Section 6. Clay, brownishblack (5YP 2/1) medium soft, somewhat plastic, massive, very fossiliferous with probable small broken shells and microfossils. Core is homogeneous throughout vertical extent.

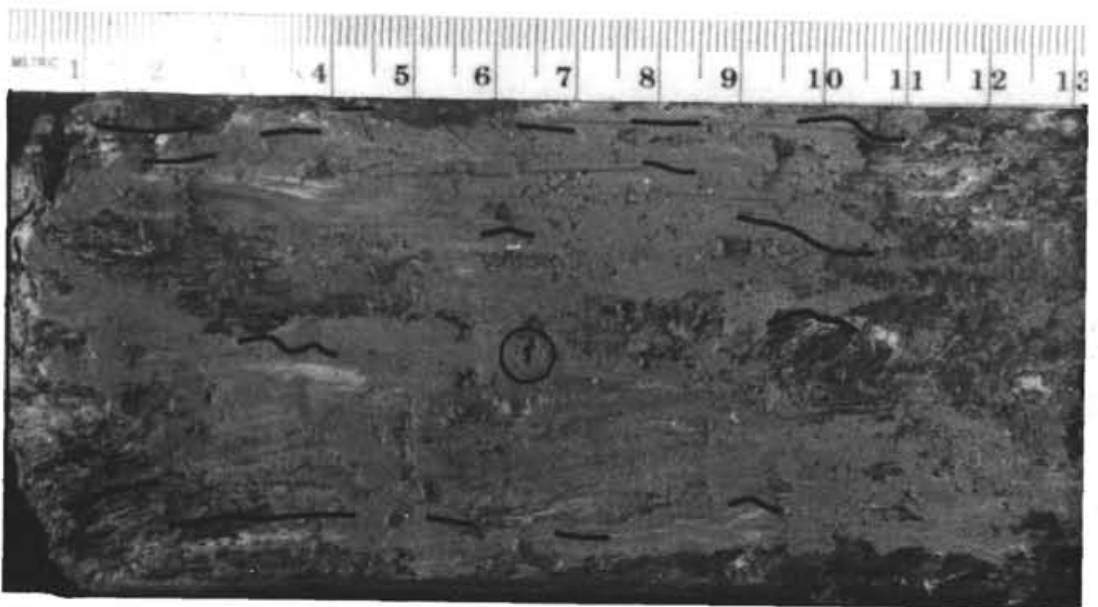

Figure 17. Leg 27, Site 259, Core 9, Section 5. Dark yellowish-brown (10YR 4/2) soft, very plastic, very soft silty clay with contorted bedding: Bedding being parallel to core axis. Contains very pale orange (10YR 8/2) laminae. 


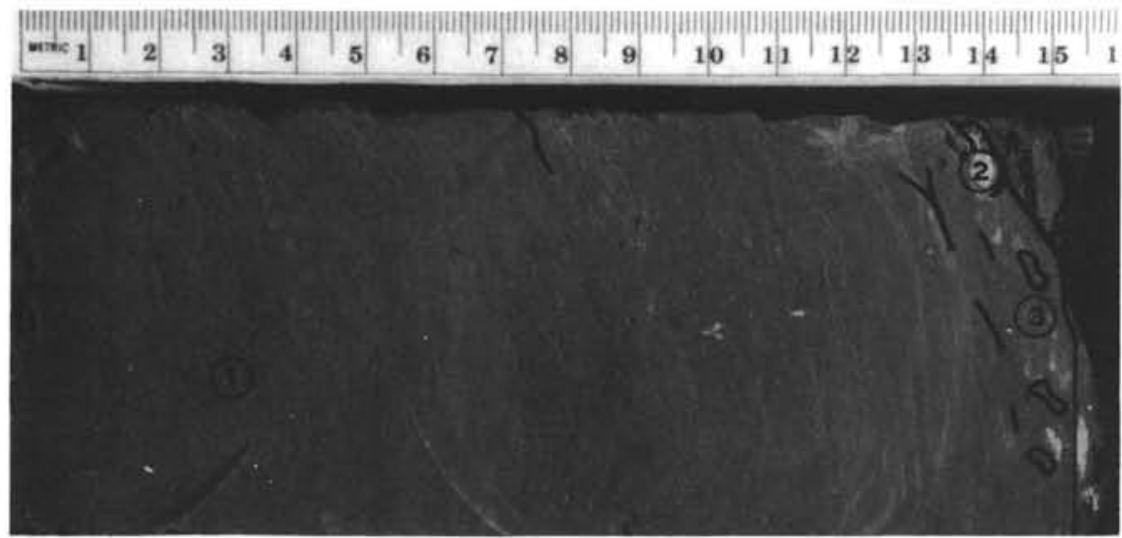

Figure 18. Leg 27, Site 263, Core 6, Section 5. Clay, dark gray (N-3), soft, plastic, massive; 1-cm layer at top composed of yellowish-gray blebs approximately $5 \mathrm{~mm}$ in length. Remainder of core is homogeneous.

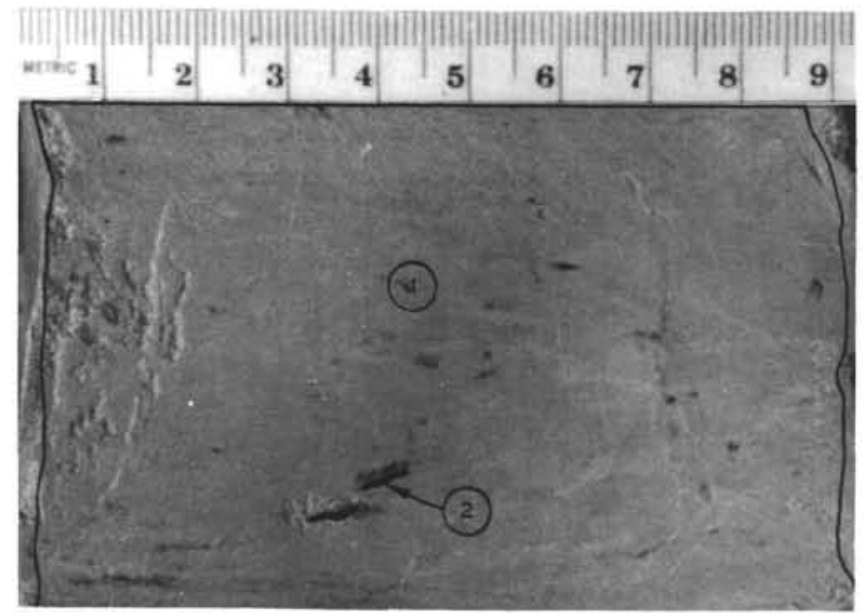

Figure 19. Leg 28, Site 267 (Hole 267A), Core 2, Section 5. Silty clay, moderate yellowish-brown (10 YR 5/4), very soft. Water impregnated with $0.5-1.0 \mathrm{~mm}$ of probably inorganic sulfide. Bedding is homogeneous throughout vertical extent.

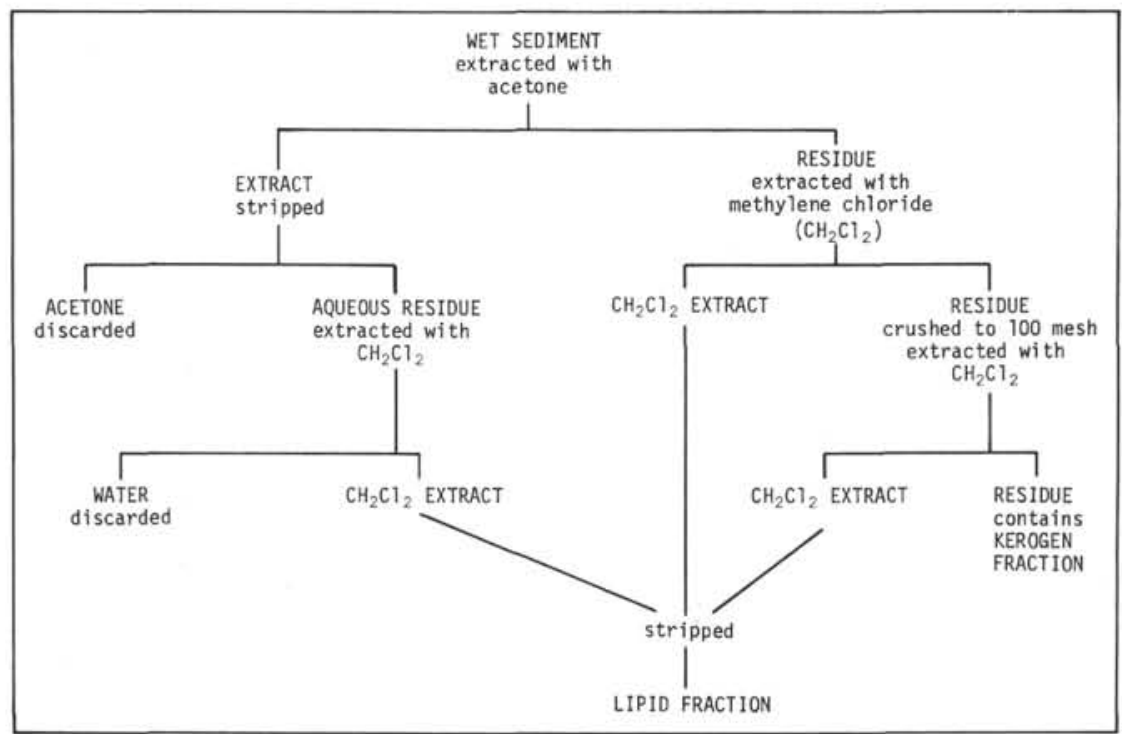

Figure 20. Flow diagram for separation and determination of carbon species. 
TABLE 2

Carbonate Content and Concentrations of Organic Fractions in Geochemical Samples from DSDP Legs 22, 24, 26, 27, and 28

\begin{tabular}{|c|c|c|c|c|c|c|c|c|}
\hline \multirow[b]{2}{*}{ Sample } & \multirow[b]{2}{*}{ Age $^{a}$} & \multirow{2}{*}{$\begin{array}{l}\text { Subbottom } \\
\text { Depth }(\mathrm{m})\end{array}$} & \multicolumn{2}{|c|}{ Carbonate (wt \%) } & \multicolumn{3}{|c|}{ Organic Carbon (wt \%) } & \multirow[b]{2}{*}{ Total Lipid } \\
\hline & & & Carbon & $\mathrm{CaCO}_{3}$ & Total & Lipid & Kerogen & \\
\hline $22-217 \mathrm{~A}-1-3$ & Quaternary & $3.0-3.2$ & 6.52 & 54.33 & 0.31 & 0.013 & 0.30 & 0.042 \\
\hline $22-217-4-4$ & Upper Miocene & $120.5-120.7$ & 8.54 & 7116 & 0.24 & 0.003 & 0.24 & 0.012 \\
\hline $22-217-8-5$ & Late Oligocene & $272.5-272.7$ & 10.21 & 85.08 & 0.05 & 0.003 & 0.05 & 0.060 \\
\hline $22-217-15-2$ & Paleocene & $403.5-403.7$ & 7.60 & 63.33 & 0.06 & 0.004 & 0.06 & 0.067 \\
\hline $22-217-19-3$ & $\begin{array}{l}\text { Upper Cretaceous/ } \\
\text { Late Maestrichtian }\end{array}$ & $443.0-443.5$ & 10.68 & 89.00 & 0.05 & 0.001 & 0.05 & 0.020 \\
\hline $22-218-4-2$ & Pleistocene & $47.5-47.7$ & 0.63 & 5.25 & 0.60 & 0.019 & 0.58 & 0.032 \\
\hline $22-218-24-2$ & Middle Miocene & $655.5-655.7$ & 2.50 & 20.83 & 0.33 & 0.015 & 0.32 & 0.045 \\
\hline $22-218-26-2$ & Middle Miocene & $731.2-731.3$ & 1.40 & 11.67 & 0.32 & 0.013 & 0.31 & 0.041 \\
\hline $24-233 A-1-3$ & Lower Pliocene & $171.0-171.2$ & 6.25 & 52.08 & 2.61 & 0.124 & 2.49 & 0.048 \\
\hline $24-233-19-5$ & Lower Pliocene & $173.7-173.8$ & 5.42 & 45.17 & 1.85 & 0.070 & 1.78 & 0.038 \\
\hline $24-233 A-7-4$ & Lower Pliocene & $230.1-230.3$ & 5.74 & 47.83 & 3.26 & 0.206 & 3.41 & 0.063 \\
\hline $24-232 A-15-2$ & Upper Miocene & $292.2-292.4$ & 3.34 & 27.83 & 1.48 & 0.014 & 1.47 & 0.009 \\
\hline $26-250 A-10-6$ & Lower Pliocene & $406.1-406.3$ & 0.71 & 5.92 & 0.29 & 0.010 & 0.28 & 0.034 \\
\hline $26-254-25-6$ & & $220.2-220.4$ & 0.23 & 1.92 & 2.81 & 0.088 & 2.72 & 0.031 \\
\hline $26-257-9-3$ & Cretaceous (Albian) & $248.2-248.4$ & 0.08 & 0.67 & 0.04 & 0.006 & 0.034 & 0.150 \\
\hline $27-259-9-5$ & Cretaceous (Albian?) & $81.8-82.0$ & 0.09 & 0.75 & 0.07 & 0.005 & 0.065 & 0.071 \\
\hline $27-263-6-5$ & Cretaceous & $148.8-149.0$ & 0.68 & 5.67 & 0.70 & 0.045 & 0.655 & 0.064 \\
\hline $28-267 A-2-5$ & & $1.4-1.5$ & 0.08 & 0.67 & 0.10 & 0.006 & 0.094 & 0.060 \\
\hline
\end{tabular}

aFrom DSDP Summary Report.

bBelow seabottom.

TABLE 3

Carbon Isotopic Composition of Lipid and Kerogen Fractions in Geochemical Samples from DSDP Legs 22, 24, 26, 27, and 28

\begin{tabular}{llcc}
\hline & \multicolumn{3}{c}{ Carbon Isotopic Composition, $\delta C^{13}$ PDB } \\
\cline { 2 - 4 } \multicolumn{1}{c}{ Sample } & Lipid & Kerogen & Difference L $-\mathrm{K}$ \\
\hline $22-217 \mathrm{~A}-1-3$ & -24.4 & -20.4 & -4.0 \\
$22-217-4-4$ & -24.3 & -21.5 & -2.8 \\
$22-217-8-5$ & -26.7 & -20.8 & -6.1 \\
$22-217-15-2$ & -25.9 & -27.9 & 2.0 \\
$22-217-19-3$ & -29.4 & -24.6 & -4.8 \\
$22-218-4-2$ & -23.8 & -18.5 & -5.3 \\
$22-218-24-2$ & -25.6 & -19.5 & -6.1 \\
$22-218-26-2$ & -27.4 & -23.8 & -3.6 \\
$24-233 \mathrm{~A}-1-3$ & -21.5 & -20.8 & -0.7 \\
$24-233-19-5$ & -21.5 & -20.0 & -1.5 \\
$24-233 \mathrm{~A}-7-4$ & -20.8 & -19.7 & -1.1 \\
$24-232 \mathrm{~A}-15-2$ & -22.8 & -18.1 & -4.7 \\
$26-250 \mathrm{~A}-10-6$ & -21.5 & -23.6 & 2.1 \\
$26-254-25-6$ & -28.3 & -29.6 & 1.3 \\
$26-257-9-3$ & -25.6 & -20.7 & -4.9 \\
$27-259-9-5$ & -26.3 & -25.1 & -1.2 \\
$27-263-6-5$ & -28.0 & -24.6 & -3.4 \\
$28-267 \mathrm{~A}-2-5$ & -27.6 & -21.4 & -6.2 \\
\hline
\end{tabular}

active carbonate deposition is taking place (Degens, 1969). There is a possible correlation of carbon isotopic composition of kerogen with depth. Similar variations in recent sediment organic matter have been shown to reflect changes in environment of deposition (Scanlan and Morgan,1970; Gearing and Parker, 1973).

An isolated sample from the Natal Basin south of Madagascar (Hole 250A), is a gray, soft, calcareous, clay mud. It contains a moderate amount of organic matter which is isotopically heavy as in the Gulf of Oman samples. It is unusual that the kerogen fraction is isotopically lighter than the lipid sample.

A single sample from the southern end of Ninetyeast Ridge (Hole 154), is a dark brown fossiliferous clay mud. It has an unusually high concentration of organic matter but, unlike the Gulf of Oman samples, the organic carbon is isotopically light ( $\mathrm{C}^{13}$ depleted). Values in this range usually are encountered in shelf areas and may reflect contributions of terrestrial organic matter to these sediments (Sackett and Thompson, 1963; Degens, 1969).

The samples from the three holes adjacent to Western Australia show marked differences in a north-south direction. The Cretaceous clay mud samples from Sites 257 and 259 are yellow to reddish-brown in color, and low in organic matter; whereas the Cretaceous sample from Site 263 is dark gray with a more than 10 -fold higher organic content. The isotopic composition of the lipid fraction also is considerably more negative ( $\mathrm{C}^{13}$ depleted) than the samples from the holes to the south.

The sample from Hole $267 \mathrm{~A}$ in the Southern Indian Basin is a yellowish-brown, soft, silty clay low in both organic and carbonate carbon contents. Isotopic compositions are typical of deep-sea sediments.

\section{REFERENCES}

Degens, E. T., 1969. Biogeochemistry of stable carbon isotopes, In Eglinton, G. and Murphy, M.T.J., Sr., (Ed.), Organic geochemistry, methods and results: New York (Springer Verlag), p 304-329.

Gearing, P. J. and Parker, P. L., 1973. Stable carbon isotope ratios of organic matter from continental margins: Ann. Meeting Geochem. Soc. Paper, 17th, Dallas, Texas.

Scanlan, R.S. and Morgan, T. D., 1970. Isotope ratio mass spectrometer instrumentation and application to organic matter contained in recent sediments. Int. J. Mass Spectrom. Ion Phys., v. 4, p. 267-281.

Sackett, W. M. and Thompson, R. R., 1963. Isotopic organic carbon composition of recent continental derived clastic sediments of Eastern Gulf Coast, Gulf of Mexico. Am. Assoc. Petrol. Geol. Bull., v. 47, p. $525-531$. 